Lingua Rima: Jurnal Pendidikan Bahasa dan Sastra Indonesia

Vol. 10 No. 3 September 2021

http://jurnal.umt.ac.id/index.php/lgrm

\title{
PENGARUH MEDIA PEMBELAJARAN APLIKASI WATTPAD TERHADAP KEMAMPUAN MENULIS TEKS DRAMA SISWA KELAS VIII SMP ISLAM YASPIA
}

\author{
Putri Harum Aulia ${ }^{1}$, \\ Universitas Singaperbangsa Karawang \\ shinhyera33@yahoo.com \\ Slamet Triyadi ${ }^{2}$ \\ Universitas Singaperbangsa Karawang \\ slamet.triyadi@fkip.unsika.ac.id \\ Hendra Setiawan ${ }^{3}$ \\ Universitas Singaperbangsa Karawang \\ hendra.setiawan@fkip.unsika.ac.id
}

\begin{abstract}
ABSTRAK
Tujuan penelitian ini untuk mengetahui keefektifan media pembelajaran aplikasi wattpad dalam menulis naskah drama pada siswa kelas VIII SMP Islam Yaspia. Penelitian ini menggunakan pendekatan kuantitatif dengan metode ekperimen dan desain penelitian Pre-eksperimental design. Siswa akan diberikan perlakuan setelah pretest dan sesudah posttest. Subjek penelitian ini adalah kelas VIII A SMP Islam Yaspia yang berjumlah 31 siswa. Instrumen penelitian terdiri dari lembar observasi, lembar hasil tes siswa dan lembar kuesioner. Teknik pengumpulan data terdiri dari lembar hasil tes, lembar kuesioner dan dokumentasi. Prosedur penelitian yang digunakan adalah (1) Pretest, (2) Perlakuan atau treatment, (3) Posttest. Berdasarkan hasil penelitian nilai rata-rata tes awal (pretest) kelas eksperimen memperoleh 63,03 dengan nilai simpang baku adalah 7,931. Nilai rata-rata tes akhir (posttest) kelas eksperimen memperoleh peningkatan yaitu 79,48 dengan nilai simpang baku adalah 6,109. Selain itu hasil uji hipotesis (T-test) kelas eksperimen adalah $0,000<$ dari 0,05 dan Thitung > dari Ttabel yaitu 9,150 > 2,042, maka H0 ditolak dan Ha diterima. Berhasilnya implementasi tersebut dapat dilihat juga dari sikap siswa setelah berlatih menulis naskah drama menggunakan aplikasi wattpad. Oleh karena itu, media aplikasi wattpad tredapat pengaruh menulis naskah drama pada siswa kelas VIII SMP Islam Yaspia.
\end{abstract}

Kata kunci: Aplikasi Wattpad, Menulis Teks Drama

\section{A. PENDAhULUAN}

Bahasa Indonesia merupakan mata pelajaran yang wajib di sekolah. Mata pelajaran Bahasa Indonesia terdiri dari empat komponen kemampuan berbahasa yang meliputi mendengarkan, berbicara, membaca dan menulis, dari keempat komponen tersebut kegiatan menulislah yang paling sulit dilakukan, sebab menulis tidak hanya menyalin kata-kata, Pengaruh Media Pembelajaran Aplikasi Wattpad terhadap Kemampuan Menulis Teks Drama Siswa Kelas VIII SMP Islam Yaspia 


\section{Lingua Rima: Jurnal Pendidikan Bahasa dan Sastra Indonesia \\ Vol. 10 No. 3 September 2021 \\ http://jurnal.umt.ac.id/index.php/lgrm}

melainkan menuangkan ide dan gagasan. Menulis merupakan kegiatan yang produktif dan ekspresif untuk menghasilkan tulisan berdasarkan pengembangan ide penulis. Dalam kegiatan menulis ini, penulis haruslah terampil memanfaatkan grafologi struktur bahasa dan kosa kata. keterampilan menulis ini tidak akan datang secara otomatis, tetapi harus melalui latihan dan praktik yang banyak dan teratur (Tarigan, 2008: 4). Menulis merupakan kegiatan yang menghasilkan suatu karya tulis yang menggunakan bahasa tulis sebagai alat penyampaian makna atau maksud, namun kegiatan ini tidaklah mudah dilakukan. Oleh karena bukan hanya menuangkan apa yang ada dalam ide atau gagasan penulis, tapi perlu mengikuti kaidah atau aturan gramatikal yang sudah ditetapkan dalam Bahasa Indonesia.

Menulis juga perlu dilakukan secara berulang untuk mengasah keterampilan tulis, semakin sering berlatih akan semakin baik dan handal dalam menulis. Penulis yang ahli dan berpengalaman, sangat pandai dalam menyempurnakan kalimat dengan pemilihan kata (diksi) dan struktur kalimat yang tepat sehingga karya tulis indah dibaca, enak didengar dan mudah dipahami oleh siapa pun. Menulis merupakan kegiatan berkomunikasi yang berupa penyampaian pesan (infomasi) secara tertulis ke pada pihak lain dengan menggunakan bahasa tulis sebagai alat atau medianya (Dalman, 2015: 3). (Siti dan Rahmah, 2018: 1) menulis merupakan kegiatan yang berikan banyak manfaat Pada dasarnya menulis merupakan kegiatan yang menyampaikan suatu informasi atau ide gagasan dengan bahasa tulis dalam menyampaikan maksudnya kepada pembaca. Menurut Ajidarma (Yunus, 2015: 24), menulis adalah suatu cara untuk bicara, suatu cara untuk berkata, suatu cara untuk menyapa, suatu cara untuk menyentuh seseorang yang lain entah dari mana. Cara itulah yang bermacam-macam dan di sanalah harga kreatifitas ditimbang-timbang. Sederhananya, menulis itu menghasilkan suatu pendapat dalam bentuk tulisan yang menggambarkan ekpresi penulis baik itu ide, gagasan, dan perasaan dengan maksud dan tujuan tertentu.

Pada tingkat sekolah menengah pertama seharusnya siswa sudah memiliki kemampuan menulis yang baik, namun minimnya pengetahuan, rendahnya tingkat membaca dan menyimak menyebabkan keterbatasan ide dan kesulitan dalam mengungkapkan idenya. Sebaliknya, seorang siswa yang mampu menulis dengan baik berarti ia memiliki wawasan yang luas sehingga memudahkannya dalam menulis, karena siswa tersebut memiliki daya kreativitas dan imajinasi yang tinggi. Menulis juga memerlukan latihan yang optimal. 


\section{Lingua Rima: Jurnal Pendidikan Bahasa dan Sastra Indonesia \\ Vol. 10 No. 3 September 2021 \\ http://jurnal.umt.ac.id/index.php/lgrm}

Maksudnya, latihan yang optimal yaitu latihan yang terus menerus tanpa putus asa dan mau mencari solusi ketika menemui suatu masalah. Kesulitan menulis yang dialami siswa, salah satunya yaitu menulis naskah drama. Teks drama adalah teks yang berisi cerita atau permasalahan kehidupan manusia dalam bentuk dialog atau percakapan yang menggambarkan karakter manusia dalam perannya masing-masing. Menurut (Hasanuddin, 2015: 2) Meskipun drama ditulis dengan tujuan untuk dipentaskan, tidaklah berarti bahwa semua karya drama yang ditulis pengarang haruslah dipentaskan. Tanpa dipentaskan sekalipun, karya drama tetap dapat dipahami, dimengerti, dan dinikmati.Sebelum melakukan proses menulis naskah drama, siswa memerlukan pemahaman yang tinggi untuk bisa menganalisis struktur, ciri-ciri dan unsur-unsur khusus yang terdapat dalam sebuah drama. Pada umumnya menulis teks drama tidaklah mudah, diperlukan kreatifitas, imajinatif, ekspresifdan memilih esensi cerita yang tidak klise, oleh karena itu perlu dilatih secara mengulang, agar tulisan menjadi lebih hidup dan menarik untuk dibaca. Menulis drama juga perlu keterampilan memasuki emosi atau perasaan yang diperankan tokoh-tokoh dalam cerita, agar tidak ambigu dan miskonsepsi dalam menafsirkan makna dari drama tersebut. Dialog yang digunakan hendaklah menggunakan diksi yang tepat agar dapat memuculkan emosi yang sesuai dengan dialog.

Adapun faktor yang mempengaruhi rendahnya minat menulis siswa. seperti faktor dari seorang pengajar (guru) maupun dari siswa. faktor dari siswa yaitu rendahnya minat dan ketertarikan siswa dalam menulis, minimnya wawasan dan pengetahuan, selain itu pengaruh lingkungan atau pergaulan, media komunikasi (handphone) dan lain-lain. faktor dari seorang pengajar (guru) seperti penyampaian materi pembelajaran dengan menggunakan teknik atau metode yang cenderung teoritis, sedikit membosankan atau kurang menarik konsentrasi dan minat siswa dalam proses belajar mengajar, serta kurangnya bimbingan dan latihan dalam kegiatan menulis, menjadi penyebab utama rendahnya minat menulis siswa. Guru harus lebih pandai dalam mengaplikasikan metode dan media pembelajaran dengan materi yang akan diajarkan kepada siswa, dengan begitu siswa akan bersemangat mengikuti proses belajar mengajar. Berdasarkan faktor-faktor di atas, hal penting yang perlu diperhatikan dalam proses belajar mengajar yakni penggunaan metode dan media yang tepat dan sesuai, agar perhatian siswa terpusat pada guru, mampu berkonsentrasi dan siswa dapat termotivasi dalam pembelajaran, sehingga tujuan belajar mengajar dapat terpenuhi maksimal selain itu bahan 


\section{Lingua Rima: Jurnal Pendidikan Bahasa dan Sastra Indonesia \\ Vol. 10 No. 3 September 2021 \\ http://jurnal.umt.ac.id/index.php/lgrm}

pengajaran akan lebih bervariasi dan lebih jelas maknanya. Penggunaan media dan metode harus sesuai dengan kebutuhan, antara lain: tujuan pengajaran, materi pembelajaran, respon yang diharapkan siswa setelah pembelajaran berlangsung, dan lain-lain. Selain itu, guru juga perlu memberikan perhatian dan bimbingan, terlebih lagi kendala umum yang sering terjadi yaitu kesulitan siswa dalam menemukan ide.

Berdasarkan pertimbangan, peneliti berusaha memberikan alternatif media pembelajaran dalam kegiatan menulis teks drama, yang kreatif dan imajinatif dengan menerapkan aplikasi Wattpad. Aplikasi yang dirasa mudah didapatkan dan lebih terkini dengan mengikuti era modern. Wattpad merupakan aplikasi online yang sedang tren saat ini di kalangan remaja. Aplikasi ini mudah diakses dan tanpa biaya, hanya saja memerlukan akses internet untuk dapat menggunakannya. Wattpad adalah aplikasi yang disediakan bagi penulis dan pembaca, di sini pembaca dapat memberikan masukan atau saran kepada penulis mengenai tulisannya. Wattpad-pun sudah dilengkapi hak cipta, jadi penulis tidak perlu khawatir karyanya diplagiat atau dijiplak oleh orang lain. Macam-macam karya tulis yang tersedia di aplikasi wattpad adalah artikel, novel, cerpen, puisi dan lain-lain.

Media aplikasi Wattpad merupakan aplikasi yang menyediakan berbagai macam cerita baik dalam bentuk novel bersambung, cerpen, artikel, dan lain-lain. melihat terbatasnya media yang diterapkan dalam pembelajaran teks drama, media Wattpad ini tentu akan membantu menunjang keberhasilan proses pembelajaran, serta media cenderung lebih menarik dan modern, karena menerapkan teknologi canggih masa kini yang mudah digunakan. Selain itu mampu membuka pikiran dan mengembangkan daya imajinasi siswa dengan beragam cerpen dalam aplikasi Wattpad. Wattpad ini digunakan untuk memotivasi munculnya banyak ide untuk menghasilkan satu kesatuan makna yang dapat dipahami yaitu dalam bentuk tulisan teks drama. Hal ini dimaksudkan agar siswa tertarik dalam pembelajaran Bahasa Indonesia khususnya menulis teks drama dengan adanya media wattpad. Media wattpad diharapkan efektif dalam pembelajaran menulis naskah drama siswa kelas VIII SMP Islam Yaspia.

Tujuan penelitian ini untuk mengetahui pengaruh kemampuan menulis teks drama dengan menggunakan aplikasi wattpad. Penelitian ini diimplementasikan di SMP Islam Yaspia tahun ajaran 2019-2020. Faktor inilah yang mendorong penulis melakukan penelitian Pengaruh Media Pembelajaran Aplikasi Wattpad terhadap Kemampuan Menulis Teks Drama Siswa Kelas VIII SMP Islam Yaspia 


\section{Lingua Rima: Jurnal Pendidikan Bahasa dan Sastra Indonesia \\ Vol. 10 No. 3 September 2021 \\ http://jurnal.umt.ac.id/index.php/lgrm}

tentang Penerapan Media Wattpad Dalam Pembelajaran Menulis Teks Drama Pada Siswa Kelas VIII SMP Islam Yaspia Cibarusah. Terdapat penelitian terdahulu yang dilakukan Mufti Prakosa dengan judul "Keefektifan Teknik Storyboard dalam Pembelajaran Menulis Naskah Drama pada Siswa Kelas VIII SMP Negeri 1 Karangpucung Cilacap”. Penelitian ini bertujuan untuk meningkatkan keterampilan menulis naskah drama pada siswa kelas VIII SMP Negeri 1 Karangpucung agar siswa aktif dan terampil dalam menulis naskah drama melalui teknik storyboard. Perbedaan dengan penelitian ini adalah penelitian mufti menggunakan teknik storyboard, sedangkan peneliti menggunakan media wattpad.

Penelitian ini juga relevan dengan hasil penelitian dengan judul "Peningkatan Keterampilan Menulis Naskah Drama dengan Media Boneka (Stick Wayang Orang) Pada Siswa Kelas VIII B SMP N 2 Sentolo" yang diteliti oleh Rini Winingsih. Penelitian ini menyimpulkan bahwa penggunaan media boneka dapat meningkatkan minat dan ketertarikan siswa dalam menulis, khususnya pembelajaran menulis drama. Pencapaian ini dapat dilihat dari proses perlakuan tindakan yang membuat siswa aktif, atusias, dan menjadi lebih imajinatif dalam menuangkan ide-idenya, karena dirasa media ini sangat menarik dan dapat memancing minat siswa dalam proses belajar.

\section{B. METODE PENELITIAN}

Penelitian ini menggunakan metode kuantitatif. Metode kuatitatif adalah metode penelitian yang terstruktur, terencana, tesusun dari awal hingga akhir penelitian, dan menggunakan teknik analisis angka-angka yang berupa statistika. Penelitian ini merupakan eksperimen dengan model penelitian kuasi eksperimen atau eksperimen semu. Penelitian ini termasuk ke dalam penelitian ekperimen. Kelompok eksperimen merupakan kelompok yang sengaja diberi pengaruh atau tindakkan variable-variabel tertentu. Model yang digunakan adalah model pre-experimental designs (nondesigns) dengan menggunakan One-Group Pretest-Posttest Design. (Sugiyono, 2017: 74) desain ini terdapat pretest sebelum diberi perlakuan, dengan demikian hasil perlakuan dapat diketahui lebih akurat karena dapat membandingkan dengan keadaan sebelum diberi perlakuan. Penelitian ini menggunakan satu kelompok yaitu kelompok eksperimen yang kemudian akan diberikan tes awal (pretest), perlakuan (treatment) dan tes akhir (posttest). Populasi dari penelitian ini adalah seluruh siswa kelas VIII SMP Islam Yaspia Cibarusah. Jumlah keseluruhan siswa kelas VIII sebanyak 93 siswa. Sampel yang diteliti yaitu kelas VIIIA terdiri atas 31 siswa. Teknik pengambilan Pengaruh Media Pembelajaran Aplikasi Wattpad terhadap Kemampuan Menulis Teks Drama Siswa Kelas VIII SMP Islam Yaspia 


\section{Lingua Rima: Jurnal Pendidikan Bahasa dan Sastra Indonesia \\ Vol. 10 No. 3 September 2021 \\ http://jurnal.umt.ac.id/index.php//grm}

sampel yaitu menggunakan sampling kuota (nonprobability sampling). Kelompok yang akan dijadikan sebagai sampel adalah kelas VIII A SMP Islam YASPIA, kelas ini ditunjuk karena dirasa dapat mewakili populasi lainnya dan bersifat homogen maksudnya kelas tersebut tidak didasari prestasi. Teknik pengambilan data penelitian dilakukan melalui observasi, wawancara, angket, dokumen dan triangulasi.

\section{HASIL DAN PEMBAHASAN}

Hasil penelitian yang telah dilakukan mengenai penerapan media aplikasi wattpad dalam pembelajaran menulis teks drama dijabarkan sebagai berikut.

\section{Tabel 1. Nilai Hasil Pretest Dan Posttest Kelompok Eksperimen}

\begin{tabular}{|c|c|c|c|}
\hline \multirow{2}{*}{ No } & \multirow{2}{*}{ Nama } & \multicolumn{2}{|c|}{ Kelas Eksperimen } \\
\hline & & Pretest & Posttest \\
\hline 1. & $\mathrm{AF}$ & 60 & 72 \\
\hline 2. & AN & 74 & 84 \\
\hline 3. & $\mathrm{AW}$ & 64 & 76 \\
\hline 4. & AA & 64 & 72 \\
\hline 5. & ANS & 60 & 80 \\
\hline 6. & ASS & 74 & 84 \\
\hline 7. & $\mathrm{AF}$ & 68 & 72 \\
\hline 8. & $\mathrm{D}$ & 68 & 80 \\
\hline 9. & $\mathrm{DL}$ & 52 & 76 \\
\hline 10. & FAA & 64 & 84 \\
\hline 11. & FAM & 56 & 68 \\
\hline
\end{tabular}

Pengaruh Media Pembelajaran Aplikasi Wattpad terhadap Kemampuan Menulis Teks Drama Siswa Kelas VIII SMP Islam Yaspia 
Lingua Rima: Jurnal Pendidikan Bahasa dan Sastra Indonesia

Vol. 10 No. 3 September 2021

http://jurnal.umt.ac.id/index.php//grm

\begin{tabular}{|c|c|c|}
\hline 12. GPP & 60 & 80 \\
\hline 13. GATAI & 48 & 80 \\
\hline 14. $\mathrm{HH}$ & 52 & 84 \\
\hline 15. INI & 56 & 76 \\
\hline 16. JKA & 60 & 80 \\
\hline 17. $\mathrm{MA}$ & 56 & 88 \\
\hline 18. $\mathrm{MGAG}$ & 60 & 90 \\
\hline 19. MNM & 64 & 76 \\
\hline 20. $\mathrm{MPA}$ & 68 & 80 \\
\hline 21. NS & 56 & 84 \\
\hline 22. PP & 56 & 88 \\
\hline 23. RPA & 68 & 72 \\
\hline 24. RAP & 68 & 86 \\
\hline
\end{tabular}

\begin{tabular}{llcc}
\hline 25. & RD & 74 & 68 \\
\hline 26. & RAF & 76 & 88 \\
\hline 27. & SHNA & 52 & 76 \\
\hline 28. & SNI & 64 & 84 \\
\hline 29. & TAZ & 76 & 72 \\
\hline 30. & WDAM & 76 & 80 \\
\hline 31. & ZFY & 60 & 84 \\
\hline & Jumlah & 1954 & 2464 \\
\hline
\end{tabular}

Pengaruh Media Pembelajaran Aplikasi Wattpad terhadap Kemampuan Menulis Teks Drama Siswa Kelas VIII SMP Islam Yaspia 


\section{Lingua Rima: Jurnal Pendidikan Bahasa dan Sastra Indonesia \\ Vol. 10 No. 3 September 2021 \\ http://jurnal.umt.ac.id/index.php/lgrm}

\begin{tabular}{ccc}
\hline $\begin{array}{c}\text { Nilai Rata- } \\
\text { rata }\end{array}$ & 63.03 & 79.48 \\
\hline Keterangan & $\begin{array}{c}\text { Tidak } \\
\text { tuntas }\end{array}$ & Tuntas
\end{tabular}

Berdasarkan tabel di atas dapat dilihat perbandingan antara tes awal, sebelum perlakuan dan tes akhir setelah perlakuan. Pada tes awal (pretest) nilai rata-rata yang diperoleh umumnya tidak tuntas, tidak memenuhi nilai KKM. Selain itu, nilai pada tes akhir (posttest) terdapat peningkatan dan tuntas memenuhi nilai KKM, setelah dilakukan perlakuan (treatment) dengan menerapkan media aplikasi wattpad dalam menulis teks drama. Hal ini menunjukkan bahwa pembelajaran menulis teks drama berlangsung optimal dan efektif.

\section{Analisis Nilai Rata-rata dan Simpangan baku}

Analisis deskriptif data pretest dan posttest kemampuan menulis teks drama dengan menggunakan program SPSS 21 ditunjukkan oleh tabel berikut:

\section{Tabel 2 Data Hasil Pretest dan Posttest}

N Min $\quad$ Max $\quad$ Mean Std $\quad$ Variance

Deviation

\begin{tabular}{lllllll}
\hline Pretest & 31 & 48 & 76 & 63,03 & 7,931 & 62,899 \\
\hline Posttest & 31 & 68 & 90 & 79,48 & 6,109 & 37,325
\end{tabular}

Valid N 31

(listwise)

Berdasarkan tabel 2 tersebut, bahwa nilai rata-rata pretest kelas eksperimen adalah 63,03, dan nilai simpang baku (standart deviation) kelas eksperimen adalah 7,931. Nilai ratarata posttest kelas eksperimen adalah 79,48 , dan nilai simpang baku (standart deviation) kelas eksperimen adalah 6,109. 
Lingua Rima: Jurnal Pendidikan Bahasa dan Sastra Indonesia

Vol. 10 No. 3 September 2021

http://jurnal.umt.ac.id/index.php//grm

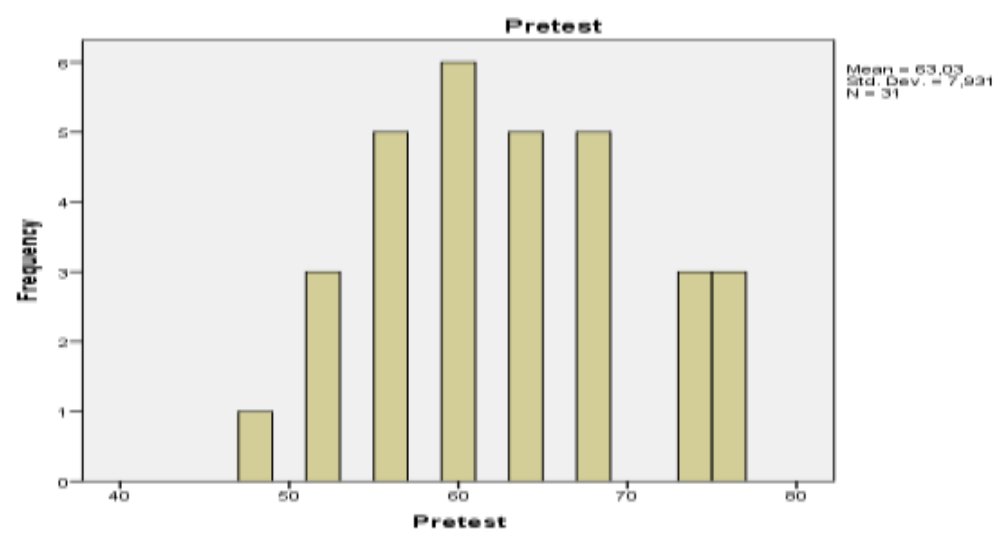

Gambar 1 pretest dan simpang baku

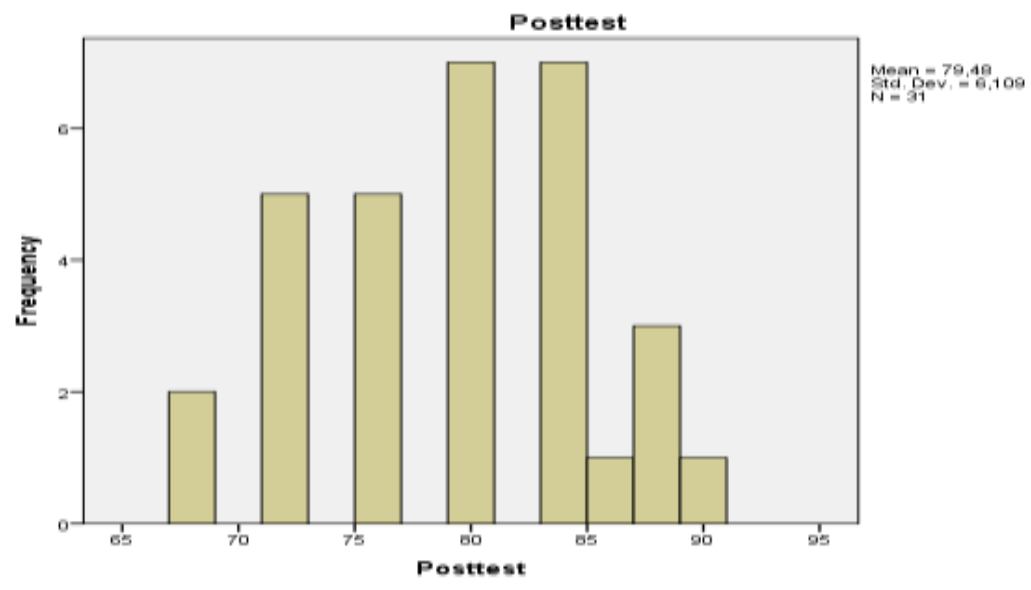

Gambar 2 posttest dan simpang baku

\section{Hasil Uji Normalitas}

Uji Nromalitas dapat dilakukan untuk mengetahui apakah dari kelas tersebut berdistribusi normal atau tidak. Uji normalitas ini menggunakan Shapiro Wilk.

\section{Tabel 3 Hasil Uji Normalitas Data Pretest dan Posttest}

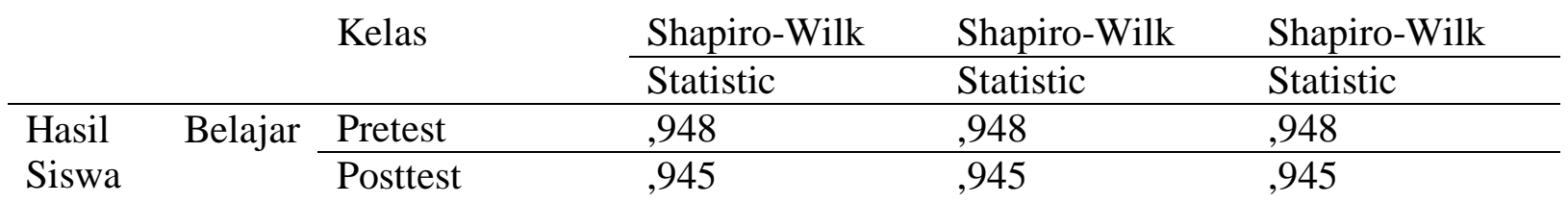




\section{Lingua Rima: Jurnal Pendidikan Bahasa dan Sastra Indonesia \\ Vol. 10 No. 3 September 2021 \\ http://jurnal.umt.ac.id/index.php//grm}

Berdasarkan tabel di atas, nilai signifikan dari kelompok eksperimen pada tes awal (pretest) adalah 0,136 dan nilai sig tes akhir (posttest) adalah 0,114, maka dapat disimpulkan bahwa data tes awal (pretest) dan tes akhir (posttest) berdistribusi normal, karena nilai sig pretest $0,136>$ dari 0,05 dan posttest $0,114>$ dari 0,05 .

\section{Hasil Uji Homogenitas}

Setelah uji normalitas, data yang diperoleh dari pretest dan posttest pada kelompok ini diuji homogenitasnya, yaitu untuk mengetahui homogen atau tidaknya (heterogen) berdasarkan sampel yang diambil dari populasi. Uji homogenitas ini menggunakan aplikasi SPSS versi 21. Data dapat dikatakan homogen bila nilai sig $>0,05$, dan apabila $<0,05$ maka bersifat heterogen.

\section{Tabel 4 Hasil Uji Homogenitas}

\begin{tabular}{llll} 
Levene Statistic & df1 & df2 & Sig. \\
\hline 2,420 & 1 & 60 &, 125
\end{tabular}

Berdasarkan tabel di atas, hasil uji homogenitas kelas eksperimen dinyatakan homogen, karena nilai sig dari kelas eksperimen adalah 0,125> dari 0,05. Maka dapat disimpulkan bahwa hasil uji homogenitas bersifat homogen.

\section{Hasil Uji Hipotesis (T-test)}

Uji hipotesis atau uji-t dihitung menggunakan bantuan aplikasi SPSS 21 dengan membandingkan mean antara tes awal (pretest) dengan tes akhir (posttest). Jika sig < dari 0,05, maka $\mathrm{H}_{0}$ ditolak dan $\mathrm{Ha}$ diterima. Sebaliknya, apabila nilai sig > dari 0,05 , maka $\mathrm{H}_{0}$ diterima dan Ha ditolak. 
Tabel 5 Hasil Uji Hipotesis (T-test)

Levene's Test for t-test for Equality of Means

Equality of Variances

\begin{tabular}{lllll}
\hline & Sig. & $\mathrm{T}$ & $\mathrm{df}$ & $\begin{array}{l}\text { Sig. } \\
\text { tailed })\end{array}$
\end{tabular}

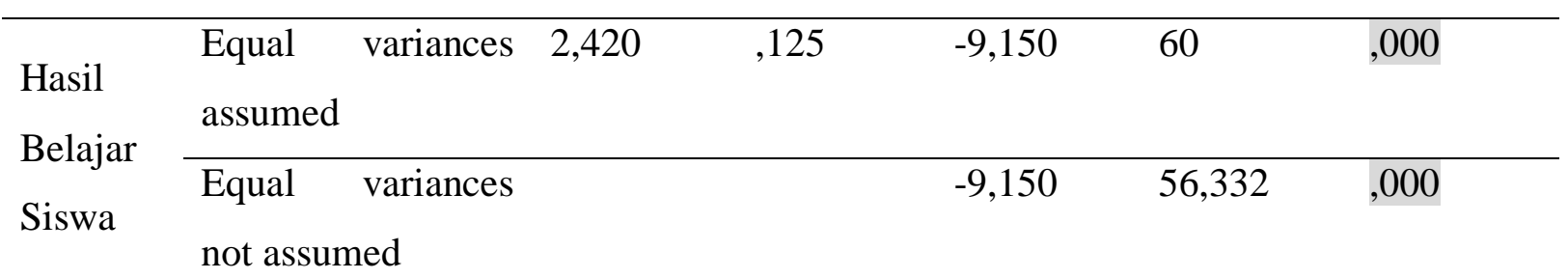

Hasil uji hipotesis (T-test) kelas ekperimen adalah sig 0,000 < dari 0,05 dan Thitung > dari Ttabel yaitu 9,150 > 2,042, maka $\mathrm{H}_{0}$ ditolak dan Ha diterima. Sehingga dapat disimpulkan bahwa terdapat perbedaan peningkatan antara sebelum dan sesudah penerapan media aplikasi wattpad dalam kemampuan menulis teks drama pada siswa kelas VIII A SMP Islam Yaspia.

\section{Pembahasan Hasil Penelitian}

Setelah rangkaian perhitungan di atas, data yang telah di peroleh dari hasil penelitian lalu dikumpulkan diolah dan dianalisis menggunakan bantuan SPSS 21. Pada bagian ini akan memaparkan hasil penelitian tersebut dalam bentuk deskripsi. Adapun isntrumen yang digunakan dalam penelitian ini berupa tes membuat teks drama. Langkah pertama yang dilakukan adalah menguji validitas dan reliabilitas untuk menentukan apakah instrumen yang digunakan layak atau tidak untuk diujicoba pada kelompok eksperimen. Uji validitas dan reliabilitas ini mengambil data pada kelas VIII SMP Islam Yaspia dengan jumlah 31 siswa yang kemudian dianalisis menggunakan aplikasi SPSS 21 untuk mengetahui nilai sig. Berdasarkan hasil data yang dianalisis dari kelompok eksperimen pada tes awal (pretest) mendapat nilai rata-rata yaitu 63,03 dan nilai rata-rata tes akhir (posttest) yaitu 79,48. Analisis kedua data tersebut dapat mengetahui pengaruh dan perbandingan sebelum dan setelah 


\section{Lingua Rima: Jurnal Pendidikan Bahasa dan Sastra Indonesia \\ Vol. 10 No. 3 September 2021 \\ http://jurnal.umt.ac.id/index.php/lgrm}

menerapkan aplikasi wattpat. Hal ini menjukkan bahwa hasil rata-rata menulis teks drama mendapat selisih yang jauh berbeda.

Selanjutnya menghitung uji normalitas untuk mengetahui normal tidaknya data yang di dapat. Uji normalitas ini menggunakan rumus Shapiro Wilk pada aplikasi SPSS 21, bertujuan untuk mengetahui normalitas dari kelompok eksperimen sebelum dan sesudah treatment (perlakuan) sebagai syarat menggunakan uji Ttest. Data yang diperoleh penelitian ini berdistribusi normal karena nilai signifikan dari kelompok eksperimen pada tes awal (pretest) adalah 0,136 > dari 0,05 dan nilai sig tes akhir (posttest) adalah 0,114> dari 0,05. Selanjutnya menghitung uji homogenitas pada data kelompok eksperimen sesudah dan sebelum treatment (perlakuan). Berdasarkan data yang diperoleh, setelah penghitungan menggunakan aplikasi SPSSI 21, didapatkan hasil nilai sig dari kelas eksperimen adalah 0,125 > dari 0,05. Maka dapat disimpulkan bahwa hasil uji homogenitas bersifat homogen.

Setelah menghitung uji homogenitas, dilanjut dengan menghitung uji hipotesis (uji Ttest). Hasil yang diperoleh dari data penelitian kelas ekperimen adalah sig $0,000<$ dari 0,05 dan Thitung > dari Ttabel yaitu 9,150 > 2,042, maka $\mathrm{H}_{0}$ ditolak dan Ha diterima. Jadi dapat disimpulkan bahwa penerapan media aplikasi wattpad pada pembelajaran menulis teks drama dapat meningkatkan kemampuan menulis siswa, karena dinilai lebih baik dan efektif. Hal ini dapat dilihat dari respon atau minat siswa saat pembelajaran berlangsung, dan hasil karya tulis siswa. Maka dapat disimpulkan bahwa penelitian ini terbukti efektif dan dapat meningkatkan kemampuan menulis teks drama pada siswa kelas VIII SMP Islam Yaspia dengan menerapkan media aplikasi wattpad.

\section{SIMPULAN DAN SARAN}

Berdasarkan hasil analisis data dan pembahasan di atas, dapat disimpulkan hasil penelitian sebagai berikut, Penerapan media aplikasi wattpad dalam pembelajaran menulis teks drama pada siswa kelas VIII A SMP Islam Yaspia. Kelas VIII A akan dijadikan sebagai sampel dan kelompok eksperimen. Kelompok eksperimen adalah kelompok yang akan diberikan treatment (perlakuan) dengan penerapan media aplikasi wattpad. Berdasarkan data yang didapat nilai rata-rata dari tes awal (pretest) adalah 63,03, sedangkan nilai rata-rata tes akhir (posttest) 79,48. Dengan demikian dapat disimpulkan bahwa penerapan media aplikasi wattpad dalam menulis teks drama dapat digeneralisasikan. Penerapan media aplikasi wattpad Pengaruh Media Pembelajaran Aplikasi Wattpad terhadap Kemampuan Menulis Teks Drama Siswa Kelas VIII SMP Islam Yaspia 


\section{Lingua Rima: Jurnal Pendidikan Bahasa dan Sastra Indonesia \\ Vol. 10 No. 3 September 2021 \\ http://jurnal.umt.ac.id/index.php//grm}

dikatakan efektif dalam pembelajaran menulis naskah drama karena memenuhi indikator keefektifan pembelajaran. Berdasarkan hasil uji hipotesis (uji Ttest) memperoleh 0,000 < dari 0,05 dan Thitung > dari Ttabel yaitu 9,150 > 2,042, hal ini membuat hipotesis alternatif (Ha) diterima dan $\left(\mathrm{H}_{0}\right)$ ditolak. Hal itu dapat dilihat dari hasil pretest dan posttest mengalami perbedaan yang signifikan, posttest mendapat nilai yang lebih tinggi dari pada pretest. Kesimpulannya adalah media aplikasi wattpad dapat meningkatkan kemampuan menulis teks drama pada siswa kelas VIII A SMP Islam Yaspia. Berdasarkan penelitian yang telah dilakukan di SMP Islam YASPIA Cibarusah, penelitian ini dapat dijadikan alternatif untuk meningkatkan dan mengembangkan kemampuan siswa dalam menulis naskah drama serta mengatasi masalah-masalah yang dialami siswa.

\section{E. DAFTAR PUSTAKA}

Ansoriyah, dkk. 2018. Menulis Populer. Bandung: PT Remaja Rosdakarya.

Arief S. Sadiman, dkk. 2009. Media Pendidikan, Pengertian,Pengembangan, dan Pemanfaatannya. Jakarta: Rajawali Press.

Dalman. 2015. Keterampilan Menulis. Jakarta: Raja Grafindo Persada.

Hasanuddin WS. 2015. Drama, Karya Dalam Dua Dimensi. Bandung: Angkasa.

Prakosa, Mufti. 2015. Keefektifan Teknik Storyboard dalam Pembelajaran Menulis Naskah Drama Pada Siswa Kelas VIII SMP Negeri 1 Karangpucung Cilacap. Skripsi.

Sugiyono. 2017. Metode Penelitian Pendidikan Pendekatan Kuantitatif. Kualitatif, dan R\&D. Bandung: Alfabeta.

Tarigan, Henry Guntur. 2008. Menulis Sebagai Suatu Keterampilan Bahasa. Bandung: Angkasa.

Winarso, Bambang. 2018. Wattpad, Surganya Penulis dan Pembaca. https://dailysocial.id diakses pada 6 Oktober 2019 pukul 2.02.

Yunus, Syarifudin.. 2015. Kompetensi Menulis Kreatif. Bogor: Ghalia Indonesia.

Winarso, Bambang. 2018. Wattpad, Surganya Penulis dan Pembaca. https://dailysocial.id diakses pada 6 Oktober 2019 pukul 2.02 .

Winingsih, Rini, 2011. Peningkatan Keterampilan Menulis Naskah Drama dengan Media Boneka (Stick Wayang Orang) Pada Siswa Kelas VIII B SMP N 2 Sentolo. Skripsi. 